\title{
The Synthesis of Polyfunctionalized, Cyclohexene-based Chirons from Tartaric Acid $\dagger$
}

\author{
Joshua N. Buckler, Brett D. Schwartz and Martin G. Banwell*
}

5 Research School of Chemistry, Institute of Advanced Studies, The Australian National University, Canberra, ACT 2601, Australia.

Email: Martin.Banwell@anu.edu.au

$\dagger$ Dedicated to Professor Masakatsu Shibasaki on the occasion of his $70^{\text {th }}$ birthday and in recognition of his sustained and outstanding contributions to chemical synthesis

\begin{abstract}
Compound ent-1 as well as certain related homochiral and polyfunctionalized cyclohexenes have been prepared from the 1,2-diacetal 4 that is itself readily derived from $L$-tartaric acid (3). Grignard addition and ring-closing metathesis processes constitute the key steps associated with the reaction sequences involved. This work provides a method for obtaining a range of potentially useful cyclohexenone-containing chirons that are enantiomerically related to those that have been prepared from the homochiral cis-1,2-dihydrocatechol 2 , the product of the microbial biotransformation of bromobenzene.
\end{abstract}

\section{Introduction}

In connection with a study focused on acetylcholine esterase (AChE) inhibitors, we prepared, over five steps, the polyfunctionalized and homochiral $\alpha$-bromocyclohexenone $\mathbf{1}$ from the enantiomerically pure cis-1,2-dihydrocatechol $2 .^{1}$ Compound 2 is the product of the microbial dihydroxylation of bromobenzene, a transformation that can be achieved particularly effectively

25 with a genetically-engineered strain of E. coli that over-expresses the enzyme toluene dioxygenase (TDO). ${ }^{2}$ In order to fully explore the biological profiles of the AChE inhibitors in question, we required the enantiomer of compound 1, namely ent-1. While a logical precursor to this 
accessible, especially in homochiral form, as congener $2 .^{3}$ Accordingly, we sought another means for obtaining chiron ent-1 as well as related systems that could serve as valuable building blocks for the synthesis of various polyoxygenated cyclohexenes and their saturated counterparts.

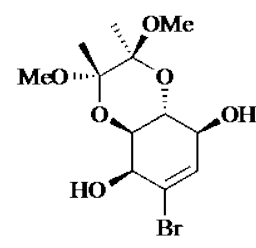

$\mathbf{1}$

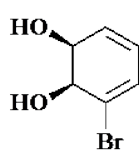

2
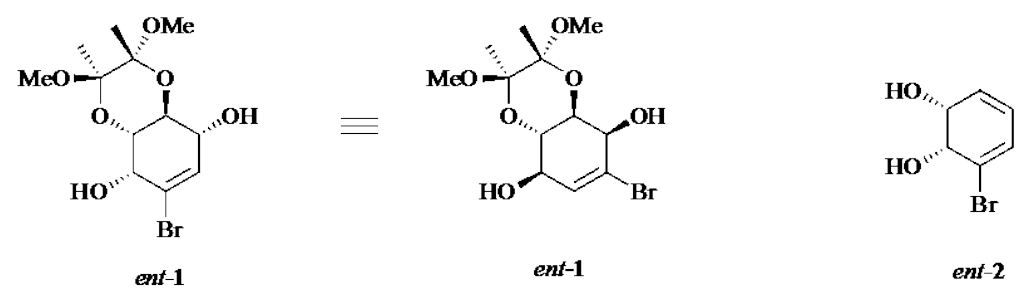

The groups of Madsen, ${ }^{4}$ Sulikowski ${ }^{5}$ and $\mathrm{Yan}^{6}$ have each demonstrated that the acetonide derived from $D$ - or $L$-tartaric acid can be elaborated, via manipulation of the derived ester residues using reduction, vinyl Grignard addition and then ring-closing metathesis (RCM) steps, into various conduritols or amino pseudosugars. Prasad has described ${ }^{7}$ closely related chemistries. The RCM products so formed incorporate rather unstable acetonide-protected trans-cyclohex-4-ene-1,2-diol moieties. On the other hand, and during the course of establishing a total synthesis the macrolide antascomicin B (a potential immunosuppressive agent), Ley ${ }^{8}$ and co-workers used a butanediacetalprotected dimethyl tartrate to construct, via a late-stage RCM, a complex cyclohexene annulated to a 1,4-dioxane and that embodies a masked and stable trans-1,2-diol. Herein we report on the exploitation of these types of protocols in the synthesis of the target chiron ent-1 as well as a range of analogues that are likely to be of value in the synthesis of a variety of biologically active systems. 


\section{Results and Discussion}

The reaction sequence that allowed for the preparation of a series of poly-oxygenated and

50 homochiral cyclohexenes from $L$-tartaric acid (3) is shown in Scheme 1 and started with the formation, under standard and operationally simple conditions, of diacetal diester 4 (72\%). While commercially available, compound $\mathbf{4}$ is easily prepared in multi-gram scale quantities from the cheap and readily available $L$-tartaric acid. Reduction of the former compound to the corresponding dialdehyde was achieved using di-iso-butylaluminium hydride (DIBAl-H) in toluene at $-78{ }^{\circ} \mathrm{C}$ and

55 this was immediately reacted with vinylmagnesium bromide ${ }^{5}$ to give the bis-olefin 5 as an inseparable mixture of diastereoisomers in $88 \%$ combined yield. This mixture was treated with the Grubbs'-II catalyst in dichloromethane and so effecting a RCM reaction and thus forming a ca. 10:6:3 mixture of the three possible stereoisomeric forms of the anticipated cyclohexene 6 in $99 \%$ combined yield.

60

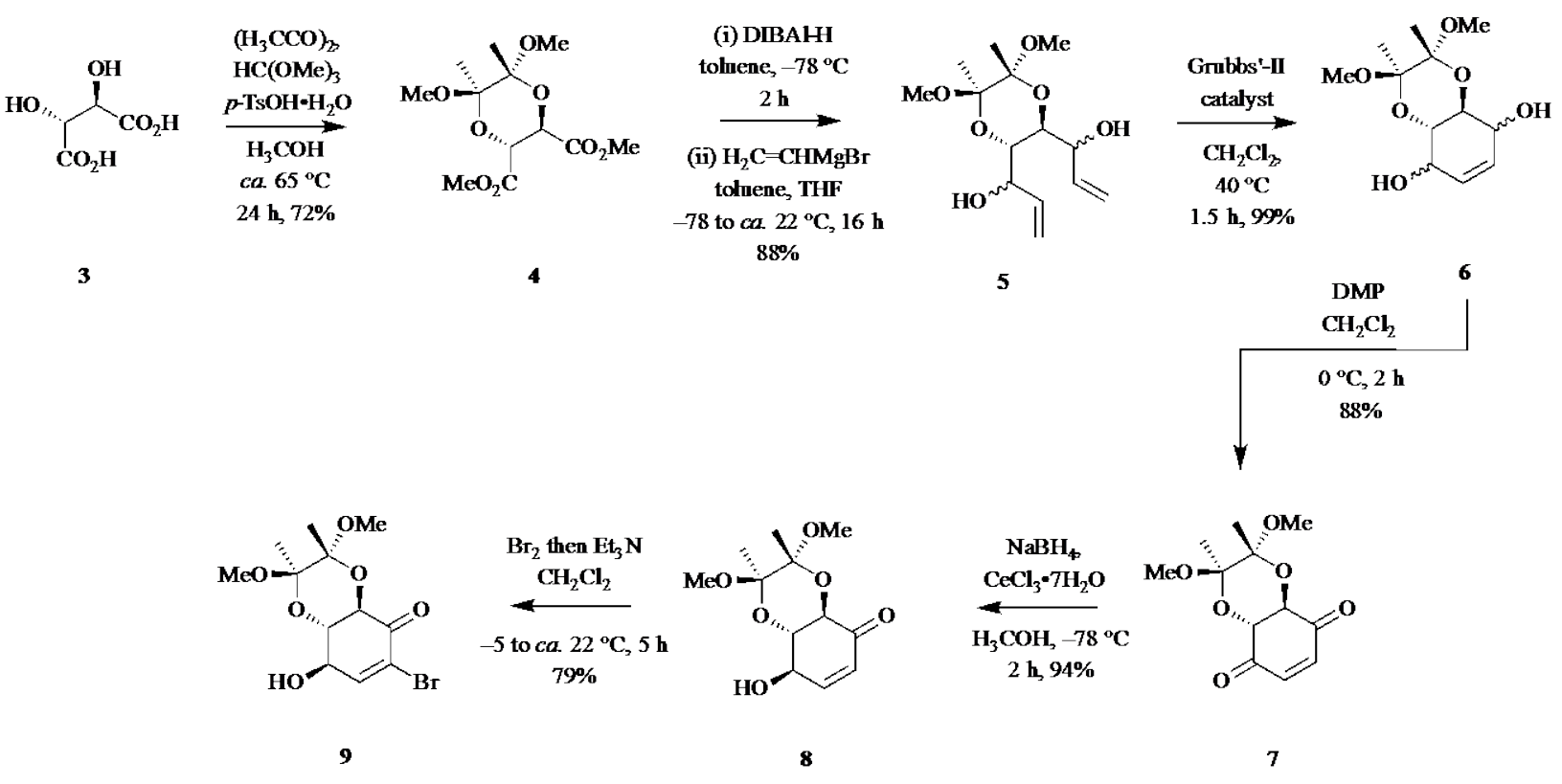

Scheme 1

65 This mixture of cyclohexenes, which was characterized as such, was subjected to a two-fold oxidation with the Dess-Martin periodinane (DMP) and so affording the corresponding enedione 7 
in $88 \%$ yield.

While enedione 7 was prone to two-fold enolization and concomitant formation of the isomeric hydroquinone, ${ }^{9}$ this $\mathrm{C}_{2}$-symmetric compound could be stereoselectively reduced to the $\gamma$ hydroxyenone 8 (94\%) under Luche-type conditions. Confirmation of the stereochemical outcome associated with this conversion, which involves axial delivery of hydride, ${ }^{10}$ was achieved through the single-crystal X-ray analysis of a halogenated derivative. Specifically, successive treatment of compound 8 with molecular bromine then triethylamine at $0{ }^{\circ} \mathrm{C}^{11}$ afforded the crystalline $\alpha$ bromoenone 9 (79\% yield) that was subjected to such an analysis. The derived ORTEP is shown in Figure 1 while other results of this analysis are provided in the Experimental Section.

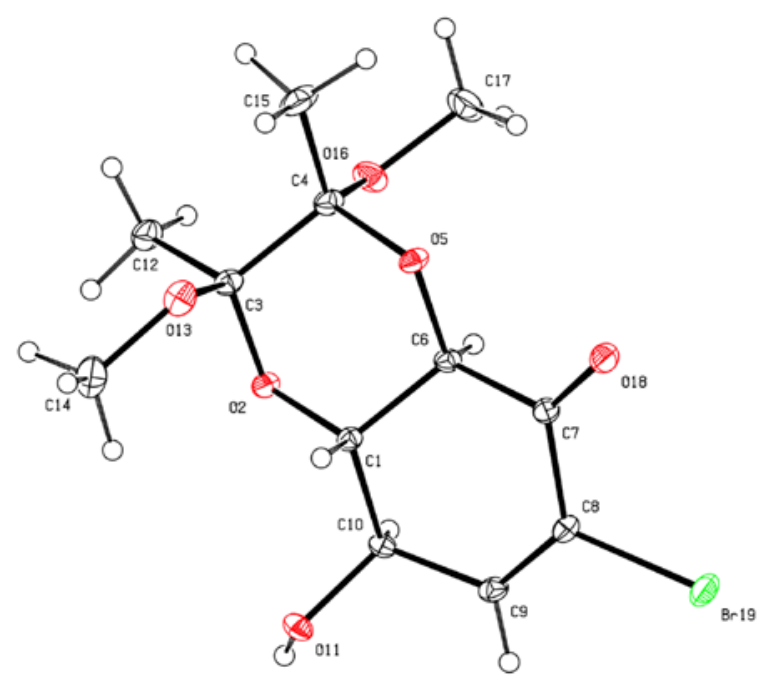

Figure 1. ORTEP derived from the single-crystal X-ray analysis of compound 9 (CCDC No. 1491822). Anisotropic displacement ellipsoids display 30\% probability levels. Hydrogen atoms are drawn as circles with small radii.

The completion of the synthesis of the target synthon ent-1 followed the pathway shown in Scheme 2 and involved the conversion of the $\gamma$-hydroxyenone $\mathbf{9}$ into the corresponding acetate, $\mathbf{1 0}$ 85 (97\%), under standard conditions. Luche reduction of compound $\mathbf{1 0}$ afforded a diastereoisomeric and chromatographically separable mixture of compounds 11 (7\%) and 12 (79\%). Subjection of the latter product to a Mitsunobu reaction, using $p$-methoxybenzoic acid as nucleophile and the 
$N, N, N, N$ '-tetramethylazodicarboxamide(TMAD)/tri-n-butylphosphine reagent combination, ${ }^{12}$ then afforded ester 13 (79\%). Finally, cleavage of this ester using potassium hydroxide in methanol gave the target ent-1 in 96\% yield.

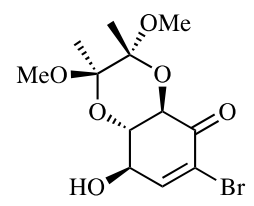

9

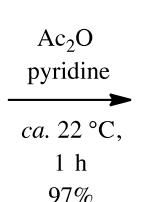

$97 \%$

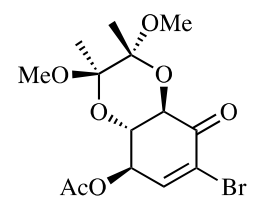

10
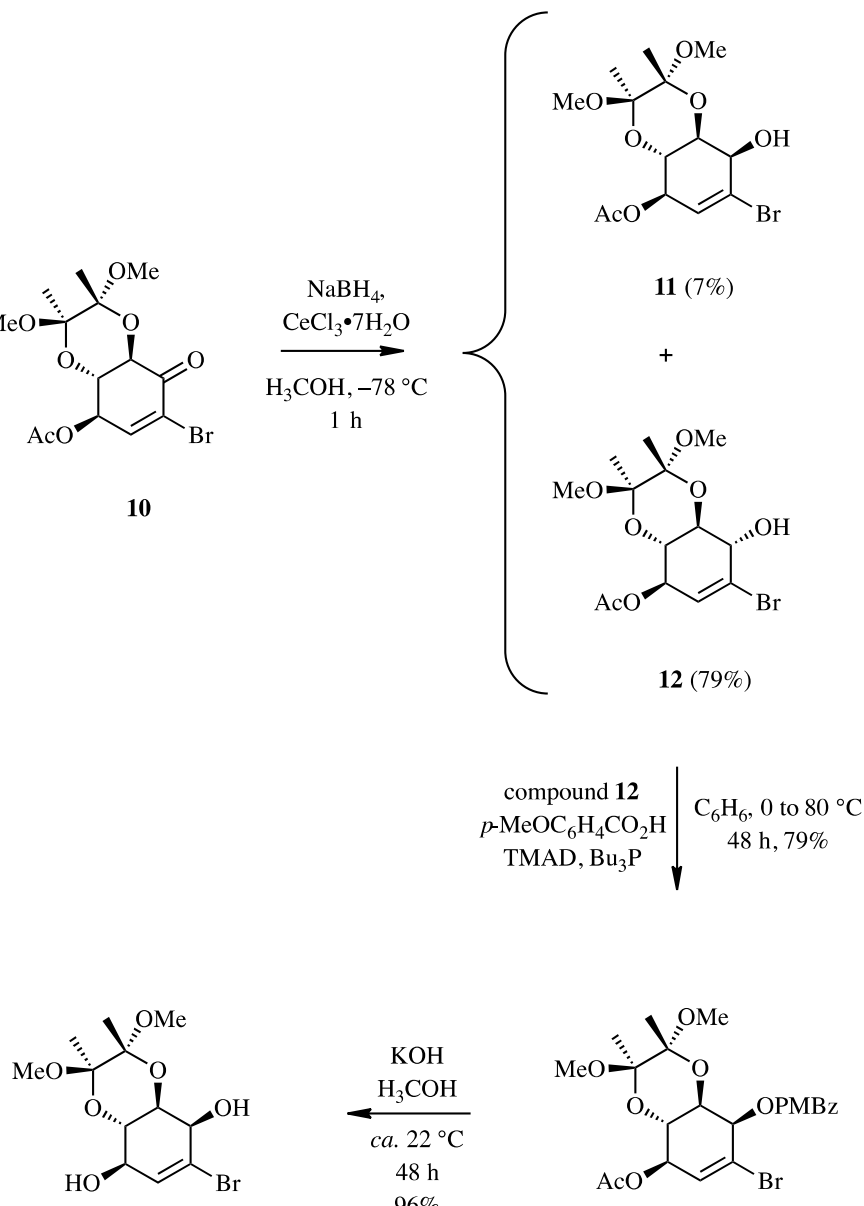

ent-1

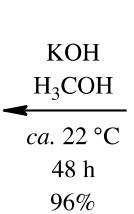

$96 \%$

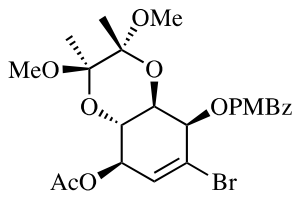

13

\section{Scheme 2}

95

The minor product, $\mathbf{1 1}$, derived from the reduction of $\alpha$-bromoenone $\mathbf{1 0}$ was readily and nearly quantitatively converted into compound ent-1 through treatment (Scheme 3) with potassium carbonate in methanol. All the spectral data acquired on compound ent-1 were consistent with the assigned structure and matched those recorded ${ }^{1}$ on its enantiomer (viz. 1) save for the specific rotation that was of similar magnitude but opposite in sign $\left\{\right.$ viz. $-76.5^{\circ}$ (c 1.0 in $\left.\mathrm{CHCl}_{3}\right)$ for ent-1 vs 
$+72.6^{\circ}\left(c=1.1\right.$ in $\left.\mathrm{CHCl}_{3}\right)$ for $\mathbf{1}$ \}. Given this relationship and that the structure of compound $\mathbf{1}$ has been established through the single-crystal X-ray analysis of a derivative, ${ }^{1}$ the illustrated stereochemical array within compound ent-1 is secure.

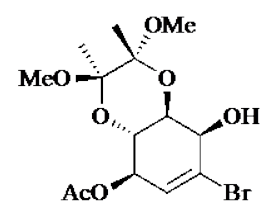

11

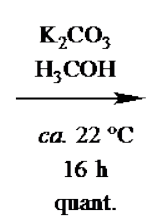

Scheme 3

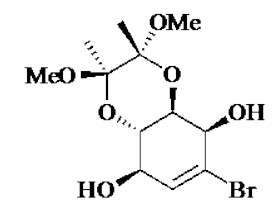

ent-1

\section{Conclusion}

Considering the ready availability of both $D$ - and $L$-tartaric acid and the demonstrated utility of polyoxygenated and halogenated cyclohexenes in the synthesis, ${ }^{2}$ the simple protocols defined above should provide a useful new means for the assembly of biologically active systems. Work directed towards such ends is now underway in our laboratories. Results will be reported in due course.

\section{Experimental}

\section{General Experimental Procedures}

115 Unless otherwise specified, proton $\left({ }^{1} \mathrm{H}\right)$ and carbon $\left({ }^{13} \mathrm{C}\right)$ NMR spectra were recorded at $18{ }^{\circ} \mathrm{C}$ in base-filtered $\mathrm{CDCl}_{3}$ on a Varian spectrometer operating at $400 \mathrm{MHz}$ for proton and $100 \mathrm{MHz}$ for carbon nuclei. For ${ }^{1} \mathrm{H}$ NMR spectra, signals arising from the residual protio-forms of the solvent were used as the internal standards. ${ }^{1} \mathrm{H}$ NMR data are recorded as follows: chemical shift ( $\delta \square \square \square$ multiplicity, coupling constant(s) (Hz), relative integral] where multiplicity is defined as:

$120 \mathrm{~s}$ = singlet; $\mathrm{d}$ = doublet; $\mathrm{t}=$ triplet; $\mathrm{q}=$ quartet; $\mathrm{m}=$ multiplet or combinations of the above. The signal due to residual $\mathrm{CHCl}_{3}$ appearing at $\delta_{\mathrm{H}} 7.26$ and the central resonance of the $\mathrm{CDCl}_{3}$ "triplet" appearing at $\delta_{\mathrm{C}} 77.1(6)$ were used to reference ${ }^{1} \mathrm{H}$ and ${ }^{13} \mathrm{C}$ NMR spectra, respectively. Infrared spectra $\left(v_{\max }\right)$ were recorded on a Perkin-Elmer UTAR Two FTIR Spectrometer. Samples were analyzed as either thin films or finely divided solids. Low-resolution ESI mass spectra were 
125 recorded on a Micromass LC-ZMD single quadrupole liquid chromatograph-mass spectrometer while high-resolution measurements were conducted on an LCT Premier time-of-flight instrument. Low- and high-resolution EI mass spectra were recorded on an Autospec Premier Micromass magnetic-sector machine. Optical rotations were recorded in $\mathrm{CHCl}_{3}$ at $20{ }^{\circ} \mathrm{C}$ on a Perkin Elmer Model 343 Polarimeter. Melting points were measured on an Optimelt automated melting point system and are uncorrected. Analytical thin layer chromatography (TLC) was performed on aluminium-backed $0.2 \mathrm{~mm}$ thick silica gel $60 \mathrm{~F}_{254}$ plates as supplied by Merck. Eluted plates were visualized using a $254 \mathrm{~nm}$ UV lamp and/or by treatment with a suitable dip followed by heating. These dips included phosphomolybdic acid : ceric sulfate : sulfuric acid (conc.) : water (37.5 g : 7.5 g : $37.5 \mathrm{~g}: 720 \mathrm{~mL}$ ) or potassium permanganate : potassium carbonate : $5 \%$ sodium hydroxide aqueous solution : water (3 g : $20 \mathrm{~g}: 5 \mathrm{~mL}$ : $300 \mathrm{~mL}$ ). Flash chromatographic separations were carried out following protocols defined by Still et $a l^{13}$ with silica gel $60(40-63 \mu \mathrm{m})$ as the stationary phase and using the AR- or HPLC-grade solvents indicated. Starting materials and reagents were generally available from the Sigma-Aldrich, Merck, TCI, Strem or Lancaster Chemical Companies and were used as supplied. Drying agents and other inorganic salts were

140 purchased from the AJAX, BDH or Unilab Chemical Companies. Diethyl ether, $N, N$ dimethylformamide (DMF), dichloromethane and ethyl acetate were dried using a Glass Contour solvent purification system that is based upon a technology originally described by Grubbs et al. ${ }^{14}$ Where necessary, reactions were performed under an inert atmosphere.

\section{Specific Experimental Procedures and Product Characterization}

\section{Compound 4}

Using a modification of a procedure reported ${ }^{15}$ by Maycock and co-workers, a magnetically stirred solution of $L$-tartaric acid (11.87 g, $79.09 \mathrm{mmol})$, 2,3-butanedione (7.25 mL, $80 \mathrm{mmol})$ and trimethyl orthoformate $(50 \mathrm{~mL}, 466 \mathrm{mmol})$ in dry methanol $(100 \mathrm{~mL})$ was treated with $p$ toluenesulfonic acid monohydrate (710 mg, $5 \mathrm{~mol} \%$ ). The resulting solution was heated under reflux for $24 \mathrm{~h}$ and the resulting deep-red mixture then cooled to room temperature and neutralised 
with $\mathrm{NaHCO}_{3}(4.00 \mathrm{~g})$. Stirring was continued for $0.5 \mathrm{~h}$ then the reaction mixture was concentrated under reduced pressure. The residue thus obtained was diluted with ethyl acetate $(100 \mathrm{~mL})$ then $\mathrm{NaHCO}_{3}$ (30 mL of a saturated aqueous solution) and the separated organic phase washed with $\mathrm{NaHCO}_{3}(1 \times 30 \mathrm{~mL}$ of a saturated aqueous solution $)$ then water $(1 \times 30 \mathrm{~mL})$. The combined aqueous layers were extracted with ethyl acetate $(3 \times 30 \mathrm{~mL})$ and the combined organic phases then washed with brine $(2 \times 20 \mathrm{~mL})$ before being dried $\left(\mathrm{Na}_{2} \mathrm{SO}_{4}\right)$, filtered and concentrated under reduced pressure. The yellow solid thus obtained was recrystallised (hexane/ethyl acetate) and the resulting solid collected and washed successively with ice-cold hexane and ice-cold ethyl acetate to give bis-ester $\mathbf{4}^{15,16}$ (16.73 g, 72\%) as an off-white, crystalline solid, m.p. $=107-108{ }^{\circ} \mathrm{C}$ (lit. ${ }^{16}$ m.p. $\left.=106-108{ }^{\circ} \mathrm{C}\right),[\alpha]_{\mathrm{D}}=-135.7^{\circ}\left(c=1.1, \mathrm{CHCl}_{3}\right)\left\{\right.$ lit. $\left.^{16}[\alpha]_{\mathrm{D}}=-139.6^{\circ}\left(c=1.0, \mathrm{CHCl}_{3}\right)\right\}$ [Found: $(\mathrm{M}+\mathrm{K})^{+}, 331.0777 . \mathrm{C}_{12} \mathrm{H}_{20} \mathrm{KO}_{8}$ requires $(\mathrm{M}+\mathrm{K})^{+}$, 331.0795]. ${ }^{1} \mathrm{H}$ NMR $\left(\mathrm{CDCl}_{3}, 400 \mathrm{MHz}\right) \delta_{\mathrm{H}} 4.54$ (s, 2H), 3.77 (s, 6H), 3.32 (s, 6H), 1.36 (s, 6H); ${ }^{13} \mathrm{C} \mathrm{NMR}\left(\mathrm{CDCl}_{3}, 100 \mathrm{MHz}\right) \delta_{\mathrm{C}} 168.6,99.4,68.9$, 52.7, 48.6, 17.5; IR (solid) $v_{\max }$ 2992, 1736, 1443, 1377, 1282, 1202, 1139, 1110, 1026, 898, 886, 810, $744 \mathrm{~cm}^{-1}$; MS (ESI, +ve) m/z $315\left[(\mathrm{M}+\mathrm{Na})^{+}, 100 \%\right]$.

\section{Compound 5}

A magnetically stirred solution of bis-ester 4 (3.10 g, $10.63 \mathrm{mmol})$ in dry toluene (30 mL) was cooled to $-78{ }^{\circ} \mathrm{C}$ then DIBAl-H (22.3 $\mathrm{mL}$ of a $1 \mathrm{M}$ solution in toluene, $\left.22.3 \mathrm{mmol}\right)$ added, via syringe-pump, over $0.75 \mathrm{~h}$. The ensuing mixture was stirred at $-78^{\circ} \mathrm{C}$ for $2 \mathrm{~h}$ then vinyl magnesium bromide (74.4 mL of a $1 \mathrm{M}$ solution in THF, $74.4 \mathrm{~mL}$ ) was added dropwise over $0.5 \mathrm{~h}$. The solution thus formed was stirred at $-78{ }^{\circ} \mathrm{C}$ for $0.5 \mathrm{~h}$ then allowed to warm to room temperature. After $16 \mathrm{~h}$ the reaction mixture was cooled to $0{ }^{\circ} \mathrm{C}$, quenched with Rochelle salt $(100 \mathrm{~mL}$ of a saturated solution: CAUTION slow addition required) then re-warmed to room temperature and stirring continued for $3 \mathrm{~h}$. The resulting biphasic mixture was transferred to a separatory funnel and the organic layer separated then washed with water $(100 \mathrm{~mL})$. The combined aqueous layers were extracted with ethyl acetate $(3 \times 30 \mathrm{~mL})$ and the combined organic phases then washed with brine $(3 \times 30 \mathrm{~mL})$ before being dried $\left(\mathrm{Na}_{2} \mathrm{SO}_{4}\right)$, filtered and concentrated under reduced pressure. The 
ensuing thick, orange oil was subjected to flash column chromatography (silica, hexane $\rightarrow 1: 1 \mathrm{v} / \mathrm{v}$ ethyl acetate/hexane gradient elution) and concentration of appropriate fractions $\left(R_{\mathrm{f}}=0.5\right.$ in $1: 1 \mathrm{v} / \mathrm{v}$ ethyl acetate/hexane) afforded bis-allylic alcohol 5 (2.69 g, 88\%) as a clear, colourless oil and a mixture of diastereoisomers [Found: $(\mathrm{M}+\mathrm{Na})^{+}$, 311.1465. $\mathrm{C}_{14} \mathrm{H}_{24} \mathrm{NaO}_{6}$ requires $(\mathrm{M}+\mathrm{Na})^{+}$, 311.1471]. ${ }^{13} \mathrm{C} \mathrm{NMR}\left(\mathrm{CDCl}_{3}, 100 \mathrm{MHz}\right) \delta_{\mathrm{C}} 138.1,138.0,136.7(2), 136.6(8), 117.2,116.8,116.1$, 115.8, 99.0, 98.9, 98.8(1), 98.7(9), 72.6, 72.3, 72.1, 71.6, 71.3, 70.5, 48.1(0), 48.0(6), 17.6(1), 17.5(9), 17.5; IR (film) $v_{\max }$ 3407, 2991, 2949, 2833, 1375, 1121, 1036, 997, 921, $852 \mathrm{~cm}^{-1}$; MS (ESI, +ve) $m / z 311\left[(\mathrm{M}+\mathrm{Na})^{+}, 100 \%\right]$

\section{Compound 6}

A solution of the bis-allylic alcohol 5 (2.67 g, $9.25 \mathrm{mmol})$ in dichloromethane $(200 \mathrm{~mL})$ was sonicated under an atmosphere of nitrogen for 0.5 h then Grubbs $2^{\text {nd }}$ generation catalyst (157 mg, 2 mol \%) was added in one portion. The ensuing mixture was heated under reflux for 1.5 hours then cooled to room temperature and the solvent removed under reduced pressure. The ensuing brown solid was subjected to flash column chromatography (silica, 1:1 v/v ethyl acetate/hexane $\rightarrow$ ethyl acetate, gradient elution) and concentration of appropriate fractions ( $R_{\mathrm{f}}=0.3$ in $2: 1 \mathrm{v} / \mathrm{v}$ ethyl acetate/hexane) afforded cyclohexene 6 (2.39 g, 99\%) as a white, amorphous solid and a mixture of diastereoisomers [Found: $(\mathrm{M}+\mathrm{Na})^{+}$, 283.1165. $\mathrm{C}_{12} \mathrm{H}_{20} \mathrm{NaO}_{6}$ requires $\left.(\mathrm{M}+\mathrm{Na})^{+}, 283.1158\right] .{ }^{13} \mathrm{C}$ NMR (CDCl $3,100 \mathrm{MHz}) \delta_{\mathrm{C}}$ 132.9, 130.0, 129.3, 126.6, 100.0, 99.8, 99.3, 99.1, 72.5, 70.6, 70.3,

69.7, 67.9, 65.9, 65.5, 65.3, 48.3, 48.2, 48.1(3), 48.0(7), 17.9(4), 17.9(0), 17.8(2), 17.8(0); IR (solid) $v_{\max }$ 3313, 2948, 1465, 1373, 1204, 1117, 1030, 971, 915, 886, $847 \mathrm{~cm}^{-1}$; MS (ESI, +ve) m/z 283 $\left[(\mathrm{M}+\mathrm{Na})^{+}, 100 \%\right]$

\section{Compound 7}

Dess-Martin periodane $(23.80 \mathrm{~g}, 53.31 \mathrm{mmol})$ was added, in portions, to a magnetically stirred solution of compound 6 (4.63 g, $17.78 \mathrm{mmol})$ in dichloromethane $(25 \mathrm{~mL})$ maintained at $0{ }^{\circ} \mathrm{C}$. After addition was complete $(0.25 \mathrm{~h})$ the cooling bath was removed and the reaction mixture was stirred at room temperature for $2 \mathrm{~h}$ before being concentrated under reduced pressure at $20{ }^{\circ} \mathrm{C}$. The residue thus obtained was subjected to rapid flash chromatography (silica, 2:8 v/v pentane/diethyl 
ether elution) and concentration of the relevant fractions $\left(R_{\mathrm{f}}=0.7\right.$ in $1: 2 \mathrm{v} / \mathrm{v}$

205 dichloromethane/diethyl ether) at $20{ }^{\circ} \mathrm{C}$ afforded enedione 7 (4.01 g, 88\%) as a bright yellow, crystalline solid, m.p. $=115-117^{\circ} \mathrm{C}($ dec. $),[\alpha]_{\mathrm{D}}=-121.0^{\circ}\left(c=0.9\right.$ in $\left.\mathrm{CHCl}_{3}\right)$ [Found: $(\mathrm{M}+\mathrm{Na})^{+}$, 279.0850. $\mathrm{C}_{12} \mathrm{H}_{16} \mathrm{NaO}_{6}$ requires $\left.(\mathrm{M}+\mathrm{Na})^{+}, 279.0845\right] .{ }^{1} \mathrm{H} \mathrm{NMR}\left(\mathrm{CDCl}_{3}, 400 \mathrm{MHz}\right) \delta_{\mathrm{H}} 6.84(\mathrm{~s}, 2 \mathrm{H})$, 4.73 (s, 2H), 3.26 (s, 6H), 1.41 (s, 6H); $\left.{ }^{13} \mathrm{C} \mathrm{NMR} \mathrm{(CDCl} 3,100 \mathrm{MHz}\right) \delta_{\mathrm{C}} 192.1,140.1,100.6,73.9$, 48.7, 17.6; IR (solid) $v_{\max }$ 2954, 2849, 1699, 1380, 1133, 1113, 1027, 823, $543 \mathrm{~cm}^{-1}$; MS (ESI, +ve) $m / z 343\left[\left(\mathrm{M}+2 \times \mathrm{CH}_{3} \mathrm{OH}+\mathrm{Na}\right)^{+}, 100 \%\right], 311\left[\left(\mathrm{M}+\mathrm{CH}_{3} \mathrm{OH}+\mathrm{Na}\right)^{+}, 50\right], 279\left[(\mathrm{M}+\mathrm{Na})^{+}, 10\right]$.

\section{Compound 8}

Sodium borohydride (770 mg, $20.35 \mathrm{mmol}$ ) was added, in portions over $0.08 \mathrm{~h}$, to a magnetically stirred solution of $\mathrm{CeCl}_{3} \cdot 7 \mathrm{H}_{2} \mathrm{O}(7.60 \mathrm{~g}, 20.40 \mathrm{mmol})$ in methanol $(50 \mathrm{~mL})$ maintained at $0{ }^{\circ} \mathrm{C}$. The ensuing mixture was stirred at this temperature for $0.25 \mathrm{~h}$ then transferred to a pressure-equalised 215 dropping funnel and added dropwise to a magnetically solution of endione 7 (4.01 g, $15.67 \mathrm{mmol}$ ) in methanol $(150 \mathrm{~mL})$ that had been cooled to $-78{ }^{\circ} \mathrm{C}$. After $1.5 \mathrm{~h}$ further portions of $\mathrm{NaBH}_{4}(5 \times 10$ mg, $1.32 \mathrm{mmol}$ ) were slowly added until the yellow reaction mixture became colourless and at which point it was quenched with acetone $(20 \mathrm{~mL})$. At this point $\mathrm{NH}_{4} \mathrm{Cl}(100 \mathrm{~mL}$ of a saturated aqueous solution) was then added to the reaction mixture so-formed and allowed to warm to room temperature. The ensuing mixture was concentrated under reduced pressure and the residue thus obtained diluted with ethyl acetate $(100 \mathrm{~mL})$ and water $(50 \mathrm{~mL})$. The separated aqueous layer was extracted with ethyl acetate $(3 \times 50 \mathrm{~mL})$ and the combined organic phases then washed with brine $(2 \times 50 \mathrm{~mL})$ before being dried $\left(\mathrm{Na}_{2} \mathrm{SO}_{4}\right)$, filtered and concentrated under reduced pressure. The residue thus generated was subjected to flash column chromatography (silica, dichloromethane $\rightarrow$ 1:2 v/v diethyl ether/ dichloromethane gradient elution) and concentration of appropriate fractions $\left(R_{\mathrm{f}}=0.21: 1 \mathrm{v} / \mathrm{v}\right.$ ethyl acetate/hexane) afforded enone 8 (3.79 g, 94\%) as a clear, colourless oil, $[\alpha]_{\mathrm{D}}$ $=-215.0^{\circ}\left(c=0.5, \mathrm{CHCl}_{3}\right)$ [Found: $(\mathrm{M}+\mathrm{Na})^{+}$, 281.1006. $\mathrm{C}_{12} \mathrm{H}_{18} \mathrm{NaO}_{6}$ requires $(\mathrm{M}+\mathrm{Na})^{+}$, 281.1001]. ${ }^{1} \mathrm{H} \mathrm{NMR}\left(\mathrm{CDCl}_{3}, 400 \mathrm{MHz}\right) \delta_{\mathrm{H}} 6.85$ (dd, $J=10.5$ and $\left.2.0 \mathrm{~Hz}, 1 \mathrm{H}\right), 6.07$ (dd, $J=10.5$ and $2.6 \mathrm{~Hz}, 1 \mathrm{H}), 4.67(\mathrm{~m}, 1 \mathrm{H}), 4.25$ (d, $J=11.4 \mathrm{~Hz}, 1 \mathrm{H}), 3.96(\mathrm{dd}, J=11.4$ and $8.7 \mathrm{~Hz}, 1 \mathrm{H}), 3.31$ 
230 (s, 3H), 3.28 (s, 3H), 2.55 (d, $J=3.9 \mathrm{~Hz}, 1 \mathrm{H}), 1.42$ (s, 3H), 1.36 (s, 3H); ${ }^{13} \mathrm{C}$ NMR $\left(\mathrm{CDCl}_{3}, 100\right.$ $\mathrm{MHz}) \delta_{\mathrm{c}} 193.5,148.6,128.4,100.3,99.4,74.3,72.3,70.1,48.7,48.2,17.7(3), 17.6(6)$; IR (film) $v_{\max } 3452,2958,1683,1379,1118,1028,967,947,881,806,634,585,540 \mathrm{~cm}^{-1}$; MS (ESI, +ve) $m / z 281\left[(\mathrm{M}+\mathrm{Na})^{+}, 100 \%\right]$.

\section{Compound 9}

235 Molecular bromine ( $400 \mu \mathrm{L}$ of a $10 \% \mathrm{v} / \mathrm{v}$ solution in dichloromethane, $0.79 \mathrm{mmol}$ ) was added, dropwise, to a magnetically stirred solution of enone 8 (185 $\mathrm{mg}, 0.72 \mathrm{mmol})$ in dichloromethane maintained at $-5{ }^{\circ} \mathrm{C}$. The resulting solution was stirred at this temperature for $1 \mathrm{~h}$ then triethylamine (300 $\mu \mathrm{L}, 2.15 \mathrm{mmol}$ ) added dropwise. The cooling bath was then removed and the reaction mixture stirred at room temperature for $16 \mathrm{~h}$ before being quenched with sodium sulfite ( 2 $240 \mathrm{~mL}$ of a saturated aqueous solution). The separated organic layer was washed successively with sodium sulfite $\left(3 \times 5 \mathrm{~mL}\right.$ of a saturated aqueous solution) and $\mathrm{NH}_{4} \mathrm{Cl}(3 \times 5 \mathrm{~mL}$ of an aqueous solution) then the combined aqueous washings were extracted with ethyl acetate $(3 \times 10 \mathrm{~mL})$. The combined organic phases were washed with brine $(2 \times 10 \mathrm{~mL})$ before being dried $\left(\mathrm{Na}_{2} \mathrm{SO}_{4}\right)$, filtered and concentrated under reduced pressure. The ensuing residue was subjected to flash column

245 chromatography (silica, dichloromethane $\rightarrow$ 1:9 v/v diethyl ether/dichloromethane gradient elution) and concentration of appropriate fractions $\left(R_{\mathrm{f}}=0.1: 9 \mathrm{v} / \mathrm{v}\right.$ diethyl ether/ dichloromethane $)$ afforded bromoenone 9 (190 mg, $79 \%)$ as a white, crystalline solid, m.p. $=178-181^{\circ} \mathrm{C},[\alpha]_{\mathrm{D}}=-146.6^{\circ}(c=$

0.5, $\left.\mathrm{CHCl}_{3}\right)$ [Found: $(\mathrm{M}+\mathrm{Na})^{+}$, 359.0100. $\mathrm{C}_{12} \mathrm{H}_{17}{ }^{79} \mathrm{BrNaO}_{6}$ requires $(\mathrm{M}+\mathrm{Na})^{+}, 359.0106$ ]. ${ }^{1} \mathrm{H}$ NMR (CDCl $3,400 \mathrm{MHz}) \delta_{\mathrm{H}} 7.29(\mathrm{~d}, J=2.3 \mathrm{~Hz}, 1 \mathrm{H}), 4.63$ (ddd, $J=8.6,4.1$ and $\left.2.3 \mathrm{~Hz}, 1 \mathrm{H}\right), 4.28$ (d, $J=11.4 \mathrm{~Hz}, 1 \mathrm{H}), 3.98$ (dd, $J=11.4$ and $8.6 \mathrm{~Hz}, 1 \mathrm{H}), 3.31$ (s, 3H), 3.28 (s, 3H), 2.57 (d, $J=4.1$

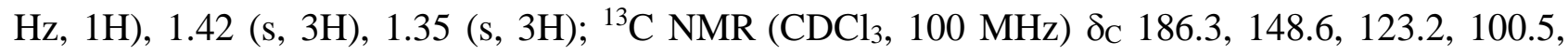
99.3, 73.6, 71.6, 70.5, 48.8, 48.3, 17.6(3), 17.5(9); IR (solid) $v_{\max } 3480,2945,1712,1601,1450$, 1373, 1334, 1279, 1205, 1141, 1110, 1023, 907, 888, 870, 858, 606, 782, 663, 606, 517, $440 \mathrm{~cm}^{-1}$; MS (ESI, +ve) m/z 361 and 359 [(M + Na) ${ }^{+}, 98$ and 100\%, respectively]. 
Acetic anhydride (120 $\mu \mathrm{L}, 1.25 \mathrm{mmol})$ was added to a magnetically stirred solution of bromoenone 9 (140 mg, $0.416 \mathrm{mmol}$ ) in pyridine $(5 \mathrm{~mL})$. Stirring was continued at room temperature for $1 \mathrm{~h}$ then the reaction mixture was concentrated under reduced pressure to afford acetate 10 (153 mg, 97\%) as a white foam, $[\alpha]_{\mathrm{D}}=-366.5^{\circ}\left(c=0.6, \mathrm{CHCl}_{3}\right)$ [Found: $(\mathrm{M}+\mathrm{Na})^{+}, 401.0217$. $\mathrm{C}_{14} \mathrm{H}_{19}{ }^{79} \mathrm{BrNaO}_{7}$ requires $\left.(\mathrm{M}+\mathrm{Na})^{+}, 401.0212\right] .{ }^{1} \mathrm{H} \mathrm{NMR}\left(\mathrm{CDCl}_{3}, 400 \mathrm{MHz}\right) \delta_{\mathrm{H}} 7.13(\mathrm{~d}, J=2.4$ Hz, 1H), 5.67 (dd, $J=8.9$ and $2.4 \mathrm{~Hz}, 1 \mathrm{H}), 4.39$ (d, $J=11.2 \mathrm{~Hz}, 1 \mathrm{H}), 4.18$ (dd, $J=11.2$ and $8.9 \mathrm{~Hz}$, 1H), 3.29 (s, 3H), 3.25 (s, 3H), 2.16 (s, 3H), 1.40 (s, 3H), 1.31 (s, 3H); $\left.{ }^{13} \mathrm{C} \mathrm{NMR} \mathrm{(CDCl}, 100 \mathrm{MHz}\right)$ $\delta_{\mathrm{C}}$ 185.9, 170.1, 144.8, 124.3, 100.5, 99.3, 71.7, 71.0, 70.6, 48.7, 48.1, 20.9, 17.6, 17.5. IR (solid) $v_{\max } 2952,1751,1720,1377,1220,1135,1113,1028,979,918,886,853,786,662 \mathrm{~cm}^{-1}$; MS (ESI, +ve) $\mathrm{m} / \mathrm{z} 467$ and 465 [(M $\left.+2 \times \mathrm{CH}_{3} \mathrm{OH}+\mathrm{Na}\right), 98$ and 100\%, respectively], 403 and 401 [(M + $\mathrm{Na})^{+}, 30$ and 29, respectively].

\section{Compounds 11 and 12}

Sodium borohydride (211 mg, $5.59 \mathrm{mmol}$ ) was added, in portions over $0.08 \mathrm{~h}$, to a magnetically stirred solution of $\mathrm{CeCl}_{3} \cdot 7 \mathrm{H}_{2} \mathrm{O}(1.09 \mathrm{~g}, 2.93 \mathrm{mmol})$ in methanol $(20 \mathrm{~mL})$ maintained at $0{ }^{\circ} \mathrm{C}$. The ensuing mixture was stirred at this temperature for $0.25 \mathrm{~h}$ then transferred to a pressure-equalised dropping funnel and added dropwise to a magnetically solution of acetate $\mathbf{1 0}$ (1.06 g, $2.79 \mathrm{mmol})$ in methanol $(100 \mathrm{~mL})$ maintained at $-78{ }^{\circ} \mathrm{C}$. After $1 \mathrm{~h}$ the reaction mixture was allowed to warm to room temperature, quenched with water $(5 \mathrm{~mL})$ and concentrated under reduced pressure. The residue thus obtained was diluted with ethyl acetate $(100 \mathrm{~mL})$ and $\mathrm{NH}_{4} \mathrm{Cl}(50 \mathrm{~mL}$ of a saturated aqueous solution). The separated aqueous layer was extracted with ethyl acetate $(3 \times 50 \mathrm{~mL})$ and the combined organic phases then washed with brine $(2 \times 50 \mathrm{~mL})$ before being dried $\left(\mathrm{Na}_{2} \mathrm{SO}_{4}\right)$, filtered and concentrated under reduced pressure. The residue thus obtained was subjected to flash column chromatography (silica, 1:19 v/v diethyl ether/dichloromethane) to afford two fractions, A and $\mathrm{B}$.

Concentration of fraction A ( $R_{\mathrm{f}}=0.3$ in $1: 19 \mathrm{v} / \mathrm{v}$ diethyl ether/dichloromethane) afforded compound $11(76 \mathrm{mg}, 7 \%)$ as a clear, colourless oil, $[\alpha]_{\mathrm{D}}=-160.0^{\circ}\left(c=0.9, \mathrm{CHCl}_{3}\right)$ [Found: $(\mathrm{M}+$ 
$\mathrm{Na})^{+}$, 403.0373. $\mathrm{C}_{14} \mathrm{H}_{21}{ }^{79} \mathrm{BrNaO}_{7}$ requires $(\mathrm{M}+\mathrm{Na})^{+}$, 403.0368]. ${ }^{1} \mathrm{H} \mathrm{NMR}\left(\mathrm{CDCl}_{3}, 400 \mathrm{MHz}\right) \delta_{\mathrm{H}}$ 6.12 (d, $J=2.5 \mathrm{~Hz}, 1 \mathrm{H}), 5.30$ (dd, $J=8.4$ and $2.5 \mathrm{~Hz}, 1 \mathrm{H}), 4.35$ (d, $J=4.0 \mathrm{~Hz}, 1 \mathrm{H}), 4.16$ (dd, $J=$ 11.0 and $8.4 \mathrm{~Hz}, 1 \mathrm{H}$ ), 3.78 (dd, $J=11.0$ and $4.0 \mathrm{~Hz}, 1 \mathrm{H}$ ), 3.27 (s, 3H), 3.26 (s, 3H), 2.74 (broad s, 1H), 2.09 (s, 3H), 1.33 (s, 3H), 1.29 (s, 3H); $\left.{ }^{13} \mathrm{C} \mathrm{NMR} \mathrm{(CDCl} 3,100 \mathrm{MHz}\right) \delta_{\mathrm{C}}$ 170.5, 130.6, 123.8, 100.1, 99.3, 72.2, 72.1, 67.6, 65.1, 48.4, 48.0, 21.1, 17.8, 17.7; IR (film) $v_{\max }$ 3475, 2950, 1750, 1733, 1371, 1230, 1135, 1116, 1033, 970, 933, 886, 851, $732 \mathrm{~cm}^{-1}$; MS (ESI, +ve) m/z 405 and 403 $\left[(\mathrm{M}+\mathrm{Na})^{+}, 100\right.$ and $98 \%$, respectively $]$.

Concentration of fraction $\mathrm{B}\left[R_{\mathrm{f}}=0.2\right.$ in $1: 19 \mathrm{v} / \mathrm{v}$ diethyl ether/dichloromethane] afforded compound 12 (840 mg, 79\%) as a clear, colourless oil, $[\alpha]_{\mathrm{D}}=-204.7^{\circ}\left(c=0.9, \mathrm{CHCl}_{3}\right)$ [Found: $(\mathrm{M}$ $+\mathrm{Na})^{+}$, 403.0367. $\mathrm{C}_{14} \mathrm{H}_{21}{ }^{79} \mathrm{BrNaO}_{7}$ requires $(\mathrm{M}+\mathrm{Na})^{+}$, 403.0368]. ${ }^{1} \mathrm{H} \mathrm{NMR}\left(\mathrm{CDCl}_{3}, 400 \mathrm{MHz}\right) \delta_{\mathrm{H}}$ 6.04 (app. t, $J=2.1 \mathrm{~Hz}, 1 \mathrm{H}), 5.38$ (m, 1H), 4.35 (m, 1H), 3.90 (dd, $J=11.0$ and $8.3 \mathrm{~Hz}, 1 \mathrm{H}$ ), 3.81 (dd, $J=11.0$ and $7.8 \mathrm{~Hz}, 1 \mathrm{H}$ ), 3.31 (s, 3H), 3.27 (s, 3H), 2.53 (s, 1H), 2.09 (s, 3H), 1.34 (s, 3H), 1.30 (s, 3H); ${ }^{13} \mathrm{C} \mathrm{NMR}\left(\mathrm{CDCl}_{3}, 101 \mathrm{MHz}\right) \delta_{\mathrm{C}} 170.3,128.5,127.1,99.4,99.2,72.1,71.8,71.4,68.6$, 48.2, 48.0, 21.1, 17.7, 17.6; IR (KBr) $v_{\max }$ 3474, 2919, 2850, 1737, 1369, 1229, 1118, 1020, 969, 914, 886, 852, 795, $736 \mathrm{~cm}^{-1}$; MS (ESI, +ve) $\mathrm{m} / \mathrm{z} 405$ and $403\left[(\mathrm{M}+\mathrm{Na})^{+}, 100\right.$ and 98\%, respectively].

\section{Compound 13}

Tri- $n$-butylphosphine $(520 \mu \mathrm{L}, 2.08 \mathrm{mmol})$ was added to a magnetically stirred solution of allylic alcohol 12 (397 mg, $1.04 \mathrm{mmol}$ ) and p-methoxybenzoic acid (316 mg, $2.08 \mathrm{mmol})$ in benzene (7 $\mathrm{mL}$ ). The solution thus obtained was cooled to $0{ }^{\circ} \mathrm{C}$ then $N, N, N^{\prime}, N^{\prime}$-tetramethylazodicarboxamide (TMAD) (376 mg, $2.08 \mathrm{mmol}$ ) was added in one portion. The ensuing mixture was stirred at $0{ }^{\circ} \mathrm{C}$ for $0.25 \mathrm{~h}$ then heated under reflux for $48 \mathrm{~h}$. The cooled solution was filtered through a short pad of diatomaceous earth and the filtrate concentrated under reduced pressure. The residue thus obtained was subjected to flash column chromatography (silica, dichloromethane $\rightarrow$ 1:19 v/v diethyl ether/dichloromethane gradient elution) and concentration of appropriate fractions $\left(R_{\mathrm{f}}=0.5\right.$ in $1: 9$ v/v diethyl ether/dichloromethane) afforded ester 13 (422 mg, 79\%) as a white, amorphous solid, 
$[\alpha]_{\mathrm{D}}=-28.3^{\circ}\left(c=1.1, \mathrm{CHCl}_{3}\right)\left[\right.$ Found: $(\mathrm{M}+\mathrm{Na})^{+}$, 537.0734. $\mathrm{C}_{22} \mathrm{H}_{27}{ }^{79} \mathrm{BrNaO}_{9}$ requires $(\mathrm{M}+\mathrm{Na})^{+}$, 537.0736]. ${ }^{1} \mathrm{H} \mathrm{NMR}\left(\mathrm{CDCl}_{3}, 400 \mathrm{MHz}\right) \delta_{\mathrm{H}} 8.05$ (d, $\left.J=8.9 \mathrm{~Hz}, 2 \mathrm{H}\right), 6.94(\mathrm{~d}, J=8.9 \mathrm{~Hz}, 2 \mathrm{H}), 6.24$

(d, $J=2.5 \mathrm{~Hz}, 1 \mathrm{H}$ ), 5.97 (d, $J=4.2 \mathrm{~Hz}, 1 \mathrm{H}), 5.37$ (dd, $J=8.5$ and $2.5 \mathrm{~Hz}, 1 \mathrm{H}), 4.28$ (dd, $J=11.1$ and $8.5 \mathrm{~Hz}, 1 \mathrm{H}$ ), 3.95 (dd, $J=11.1$ and $4.2 \mathrm{~Hz}, 1 \mathrm{H}), 3.88$ (s, 3H), 3.30 (s, 3H), 3.25 (s, 3H), 2.14 (s, 3H), 1.27 (s, 3H), 1.10 (s, 3H); ${ }^{13} \mathrm{C} \mathrm{NMR}\left(\mathrm{CDCl}_{3}, 100 \mathrm{MHz}\right) \delta_{\mathrm{C}} 170.4,165.8,163.6,132.6,132.3$, 122.5, 121.0, 113.7, 99.6, 99.3, 72.2, 71.9, 66.7, 66.0, 55.6, 48.4, 47.9, 21.1, 17.7, 17.4; IR (film) $v_{\max } 2980,1724,1605,1511,1372,1254,1226,1166,1117,1083,1051,1028,971,933,765,699$,

663, $611 \mathrm{~cm}^{-1}$; MS (ESI, +ve) m/z 539 and 537 [(M + Na) $)^{+}, 100$ and 98\%, respectively].

\section{Compound ent-1}

Method i (ex. Compound 13): Potassium hydroxide (60 mg, $1.07 \mathrm{mmol}$ ) was added to a magnetically stirred solution of compound 13 (103 mg, $0.20 \mathrm{mmol})$ in methanol $(10 \mathrm{~mL})$ and the ensuing mixture stirred at room temperature for $48 \mathrm{~h}$. The methanol was then removed under reduced pressure and the residue so obtained diluted with ethyl acetate $(10 \mathrm{~mL})$ and $\mathrm{NH}_{4} \mathrm{Cl}(10 \mathrm{~mL}$ of a saturated aqueous solution). The separated aqueous layer was extracted with ethyl acetate $(3 \times$ $5 \mathrm{~mL})$ and the combined organic phases washed with brine $(2 \times 5 \mathrm{~mL})$ before being dried $\left(\mathrm{Na}_{2} \mathrm{SO}_{4}\right)$, filtered and concentrated under reduced pressure. The resulting white solid was subjected to flash column chromatography (silica, $\rightarrow$ 1:24 v/v diethyl ether/dichloromethane gradient elution) and concentration of appropriate fractions $\left(R_{\mathrm{f}}=0.3\right.$ in $1: 19 \mathrm{v} / \mathrm{v}$ methanol/dichloromethane) afforded diol ent-1 (65 mg, 96\%) as a white foam, $[\alpha]_{\mathrm{D}}=-76.5^{\circ}\left(\right.$ c 1.0 in $\left.\mathrm{CHCl}_{3}\right)$ [Found: $(\mathrm{M}+\mathrm{Na})^{+}, 361.0260$. $\mathrm{C}_{12} \mathrm{H}_{19}{ }^{79} \mathrm{BrNaO}_{6}$ requires $\left.(\mathrm{M}+\mathrm{Na})^{+}, 361.0263\right] .{ }^{1} \mathrm{H} \mathrm{NMR}\left(\mathrm{CDCl}_{3}, 400 \mathrm{MHz}\right) \delta_{\mathrm{H}} 6.05(\mathrm{~d}, J=2.5$ Hz, 1H), 4.22 (d, $J=4.1 \mathrm{~Hz}, 1 \mathrm{H}), 4.06$ (dd, $J=7.9$ and $2.5 \mathrm{~Hz}, 1 \mathrm{H}), 3.87$ (dd, $J=11.1$ and $7.9 \mathrm{~Hz}$, 1H), 3.63 (dd, $J=11.1$ and $4.1 \mathrm{~Hz}, 1 \mathrm{H}), 3.30$ (s, 3H), 3.26 (s, 3H), 1.32 (s, 3H), 1.29 (s, 3H)

330 (signals due to hydroxyl group protons not observed); ${ }^{13} \mathrm{C} \mathrm{NMR}\left(\mathrm{CDCl}_{3}, 100 \mathrm{MHz}\right) \delta_{\mathrm{C}} 135.3,124.0$, 100.8, 100.2, 73.1, 71.8, 69.9, 69.2, 48.3(1), 48.2(5), 18.1, 18.0; IR (KBr) v $v_{\max } 3236,3007,2954$, 2905, 2834, 1114, 1074, 1054, 1030, 985, 912, 884, 852, 760, 665, 617, $599 \mathrm{~cm}^{-1}$; MS (ESI, +ve) m/z 363 and 361 [(M + Na), 98 and 100\%, respectively]. 
Method ii (ex. Compound 11): Potassium carbonate (50 mg, $0.36 \mathrm{mmol}$ ) was added to a magnetically stirred solution of ester $11(76 \mathrm{mg}, 0.20 \mathrm{mmol})$ in methanol $(10 \mathrm{~mL})$ and the resulting mixture stirred at room temperature for $12 \mathrm{~h}$ then concentrated under reduced pressure. The residue thus obtained was diluted with ethyl acetate $(10 \mathrm{~mL})$ and water $(10 \mathrm{~mL})$ then the separated aqueous layer extracted with ethyl acetate $(3 \times 5 \mathrm{~mL})$. The combined organic phases were washed with brine $(2 \times 5 \mathrm{~mL})$ before being dried $\left(\mathrm{Na}_{2} \mathrm{SO}_{4}\right)$, filtered and concentrated under reduced pressure to give enediol ent-1 (67 mg, 99\%) as a white foam. This material was identical, in all respects, with that obtained by Method i.

\section{X-ray Crystallographic Study}

\section{Crystallographic Data}

Compound 9: $\mathrm{C}_{12} \mathrm{H}_{17} \mathrm{BrO}_{6}, M$ 337.17, $T 150 \mathrm{~K}$, orthorhombic, space group $P 2{ }_{1} 2_{1} 2_{1}, Z$ 4, $a$ 6.8265(1), b 11.4217(1), c 17.8288(1) $\AA ; V$ 1390.12(1) $\AA^{3} ; D_{x} 1.611 \mathrm{~g} \mathrm{~cm}^{-3} ; 2750$ unique data $\left(2 \theta_{\max } 144.6^{\circ}\right), R 0.021$ [for 2718 reflections with $I>2.0 \sigma(I)$ ]; $R w 0.052$ (all data), $S$ 1.03.

\section{Structure Determination}

Images were measured on an Agilent SuperNova CCD diffractometer (CuKa, mirror monochromator, $\lambda 1.54184 \AA$ ) and data extracted using the CrysAlis package. ${ }^{17}$ Structure solution 350 was by direct methods (SIR92). ${ }^{18}$ The structure of compound 9 was refined using the CRYSTALS program package. ${ }^{19}$ Atomic coordinates, bond lengths and angles, and displacement parameters have been deposited at the Cambridge Crystallographic Data Centre (CCDC no. 1491822). These data can be obtained free-of-charge via www.ccdc.cam.ac.uk/data_request/cif, by emailing data_request@ccdc.cam.ac.uk, or by contacting The Cambridge Crystallographic Data Centre, 12

355 Union Road, Cambridge CB2 1EZ, UK; fax: +44 1223336033.

\section{Supplementary Material}

The ${ }^{1} \mathrm{H}$ and ${ }^{13} \mathrm{C}$ NMR spectra of compounds 4-13 and ent-1 are available on the Journal's website.

\section{Acknowledgements}


We thank the Research School of Chemistry, the Australian Research Council and Institute of

Advanced Studies for support. JNB is the grateful recipient of an Australian Postgraduate Award (APA) provided by the Australian Government.

\section{References and Footnotes}

1. J. N. Buckler, E. S. Taher, N. J. Fraser, A. C. Willis, P. D. Carr, C. J. Jackson and M. G. Banwell, manuscript in preparation.

2. For reviews on methods for generating cis-1,2-dihydrocatechols by microbial dihydroxylation of the corresponding aromatics, as well as the synthetic applications of these metabolites, see: (a) T. Hudlicky, D. Gonzalez, D. T. Gibson, Aldrichimica Acta 1999, 32, 35; (b) M. G. Banwell, A. J. Edwards, G. J. Harfoot, K. A. Jolliffe, M. D. McLeod, K. J. McRae, S. G. Stewart, M. Vögtle, Pure Appl. Chem. 2003, 75, 223; (c) R. A. Johnson, Org. React. 2004, 63, 117; (d) T. Hudlicky, J. W. Reed, Synlett 2009, 685; (e) D. J.-Y. D. Bon, B. Lee, M. G. Banwell, I. A. Cade, Chim. Oggi 2012, 30 (No. 5, Chiral Technologies Supplement), 22; (f) U. Rinner, Chiral Pool Synthesis: Chiral Pool Syntheses from cisCyclohexadiene Diols. In Comprehensive Chirality; E. M. Carreira and H. Yamamoto, Eds.; Elsevier: Amsterdam, 2012; Vol. 2, p 240. (g) S. E. Lewis, Chem. Commun., 2014, 50, 2821; (h) M. G. Banwell, B. Bolte, J. N. Buckler, E. L. Chang, P. Lan, E. S. Taher, L. V. White and A. C. Willis, Chemoenzymatic Pathways for the Synthesis of Biologically Active Natural Products. Proc. \& J. Royal Soc. New South Wales, accepted for publication.

3. (a) D. R. Boyd, N. D. Sharma, S. A. Barr, H. Dalton, J. Chima, G. Whited, R. Seemayer, J. Am. Chem. Soc., 1994, 116, 1147; (b) C. C. R.Allen, D. R. Boyd, H. Dalton, N. D. Sharma,

I. Brannigan, N. A. Kerley, G. N. Sheldrake, S. C. Taylor, J. Chem. Soc., Chem. Commun., 1995, 117.

4. M. Jørgensen, E. H. Iversen, A. L. Paulsen and R. Madsen, J. Org. Chem., 2001, 66, 4630.

5. W.-D. Lee, K. Kim and G. A. Sulikowski, Org. Lett., 2005, 7, 1687. 
6. H.-J. Lo, C.-Y. Chen, W.-L. Zheng, S.-M. Yeh and T.-H. Yan, Eur. J. Org. Chem., 2012, 2780.

7. K. R. Prasad and S. M. Kumar, Tetrahedron, 2013, 69, 6512.

8. D. E. A. Brittain, C. M. Griffith-Jones, M. R. Linder, M. D. Smith, C. McCusker, J. S. Barlow, R. Akiyama, K. Yasuda and S. V. Ley, Angew. Chem. Int. Ed., 2005, 44, 2732.

9. Sulikowski has reported ${ }^{5}$ that the acetonide-protected counterpart to enedione $\mathbf{7}$ is similarly prone to aromatization.

10. For related reductions see C. Liu and D. J. Burnell, J. Org. Chem., 1997, 62, 3683.

11. A. B. Smith III, S. J. Branca, M. A. Guaciaro, P. M. Wovkulich and A. Korn, Org. Synth., 1983, 61, 65.

12. T. Tsunoda, Y. Yamamiya, Y. Kawamura and S. Ito, Tetrahedron Lett., 1995, 36, 2529.

13. W. C. Still, M. Kahn, A. Mitra, J. Org. Chem., 1978, 43, 2923.

14. A. B. Pangborn, M. A. Giardello, R. H. Grubbs, R. K. Rosen, F. J. Timmers, Organometallics 1996, 15, 1518.

15. M. T. Barros, A. J. Burke and C. D. Maycock, Tetrahedron Lett., 1999, 40, 1583.

16. N. Bellec, A. G. Montalban, D. B. G. Williams, A. S. Cook, M. E. Anderson, X. Feng, A. G. M. Barrett and B. M. Hoffman, J. Org. Chem., 2000, 65, 1774.

17. CrysAlisPro, Agilent Technologies, Version 1.171.37.33d (release 23-04-2014 CrysAlis171.NET) (compiled 23 April 2014, 17:37:27).

18. SIR92. A. Altomare, G. Cascarano, C. Giacovazzo, A. Guagliardi, M. C. Burla, G. Polidori, M. Camalli, J. Appl. Crystallogr. 1994, 27, 435.

405 19. P. W. Betteridge, J. R. Carruthers, R. I. Cooper, K. Prout, D. J. Watkin, J. Appl. Crystallogr. 2003, 36, 1487. 